Egypt. Acad. J. biolog. Sci., 2(2): 1 - 10 (2010)

Email: egyptianacademic@yahoo.com

Received: 15/6/2010
C. Physiology \& Molecular Biology

ISSN: 2090-0767

www.eajbs.eg.net

\title{
Efficacy of the wild plant fagonia bruguieri (zygophyllaceae) on acid and alkaline phosphatase activities in the desert locust schistocerca gregaria (orthoptera: acrididae).
}

Basiouny, A. L.; Hamadah, Kh. Sh. and Tanani, M. A. Faculty of Science, Al-Azhar University Madenit Nasr, Cairo

\section{ABSTRACT}

The wild plant Fagonia bruguieri was extracted by three organic solvents in the present study. Two concentration levels of methanol extract $(7.5 \%$ and $3.7 \%)$, petroleum ether extract $(30.0 \%$ and $15.0 \%)$ or n-butanolic extract $(30.0 \%$ and $15.0 \%)$ were applied against the newly moulted penultimate instar nymphs of the desert locust Schistocerca gregaria and their effects were assessed on the acid and alkaline phosphatases (ACP and ALP) in both the haemolymph and fat body of last instar nymphs and newly emerged adults.

The haemolymph of both early- and late-aged nymphs contained remarkably reduced ACP activity while a strong enhancing effect of $F$. bruguieri was exhibited only in the early-aged nymphs after treatment with the lower concentration level of methanolic extract (Change \%: +75.0). Haemolymph of the newly emerged adults appeared with pronouncedly induced ACP activity, irrespective of the solvent or the concentration level. A major inducing effect of F. bruguieri extracts on ACP activity in the fat body in last instar nymphs was significantly or insignificantly observed, with few exceptions. The strongest inducing effect on the enzyme activity in fat body of the newly emerged adults was exhibited by n-butanol extract (Change \%: +40.9 at lower concentration level).

The F. bruguieri, extracted by all organic solvents, exerted contradictory effects on the ALP activity in haemolymph of the nymphs depending on the age because the early- and mid-aged nymphs appeared with significantly decreased enzyme activity but induced activity in the late-aged ones. A considerable enhancing effect of F. bruguieri on ALP activity in haemolymph of the newly emerged adults was determined. In respect to the ALP activity in fat body, F. bruguieri extracts prohibited it in the early- and mid-aged nymphs but stimulated it in the late-aged ones. Also, an enhancing effect on the enzyme activity in fat body of the newly emerged adults was appreciated.

Keywords: Schistocerca gregaria , Fagonia bruguieri, acid phosphatase, alkaline phosphatase, nymph, adult, haemolymph, fat body, methanol, petroleum ether, n-butanol.

\section{INTRODUCTION}

Extensive use of the synthetic insecticides leads to the biological imbalance due to the destruction of beneficial species such as parasites and predators of pests beside the destruction of pollinating insects such as honey bees. Also, the wide use of chemical insecticides had some undesirable consequences such as the development of resistant strains of many pests and growing toxic hazards to man, his livestock and wild life, in general (Schmutterer and Ascher, 1984). Therefore, there is an urgent need to search promising alternatives to the synthetic insecticides. Natural plant products act as good resource for screening some substances to the pest 
control because they are non-toxic to warm-blooded animals and show no or moderate side effects on natural enemies of insect pests (Schmutterer, 1985).

On the other hand, growth and development in insects are regulated by the steroidal moulting hormone, 20hydroxyecdysone, and the sesquiterpenoid, juvenile hormone (Smith, 1985; Rees, 1995; Dhadialla et al., 1998). Moulting hormone triggers the moulting events, whereas the character of the moult is dictated by juvenile hormone. Imbalance in the level of the two morphogenetic hormones lead to abnormal forms, i.e. prothetely or metathetely (Wigglesworth, 1972). Plants are known to contain a very diverse range of secondary metabolites such as terpenoids, alkaloids, polyacetylene, flavonoids and unusual amino acids and sugars. These compounds may protect the plants from the insect pest attacks (Benner, 1993), and act as insect repellents (Jacopson, 1975), or insect growth regulators (Rembold et al.1980). Identification of phytochemicals which mimic insect morphogenetic hormones or have growth regulating activity and synthesis of potent hormone agonists and antagonists in the recent past have led to their consideration as components of biorational approach to pest management (Josephrajkumar et al., 1999).

The hydrolytic enzymes, such as acid phosphatase (ACP) and alkaline phosphatase (ALP), are responsible for cytolysis of tissues during the insect development (Sridhara and Bhat, 1963; Schin and Clever, 1965; Dadd, 1970). Also, both ACP and ALP may act as hydrolases during the final stages of digestion (Cheug and Low, 1975), gonad maturation and metamorphic moults (Rhadha and Priti, 1969). In addition, the ACP hydrolyzes a variety of orthophosphate esters and is capable of transphosphorylation reactions to increase the phosphate pool for synthesizing higher energy compounds as adenosine triphosphate (ATP), ATP ase, and genetic materials (DNA or RNA) (Hollander, 1971).

\footnotetext{
On the other hand, ALP is a brush border membrane marker enzyme (Wolfersberger, 1984) and is especially
}

active in tissues with active membrane transport, such as intestinal epithelial cells (Ferreira and Terra, 1980) and malpighian tubules (Srivastava and Saxena, 1967; Khoja, 1991). However, ALP is located in cells which are the most in the synthesis of fibrous proteins and may be correlated to the gradual growth and development of the imaginal tissues that overlap with histolysis of the larval tissues (Bream, 2003). The purpose of the present study was to investigate the effects of different extracts from the wild plant Fagonia bruguieri on ACP and ALP activities in the haemolymph and fat body of the desert locust Schistocerca gregaria.

\section{MATERIALS AND METHODS I) The Insect Culture:}

A gregarious stock culture of Schistocerca gregaria (Forsk.) was raised by a sample from the established culture of Locust and Grasshopper Res. Division, Agric. Res. Center, Giza, Egypt. The insects were reared under crowded breeding conditions outlined by HunterJones (1961) and Hassanein (1965). Newly hatched hoppers were kept in wooden cages with wire-gauze sides $(40 \times 40 \times 60$ $\mathrm{cm})$ and small door in the upperside to allow the daily feeding and cleaning routine. The bottom was covered with 20 $\mathrm{cm}$ layer of sterilized sand. Each cages was equipped internally with $60 \mathrm{~W}$ electric bulb for lightening (17:7 LD) and warming $(32 \pm 2$ C.). The relative humidity varied from $70-80 \%$ following the introduction of fresh food plant to $60-70 \%$ several hours later. Successive generations were raised before obtaining the nymphs for the present experimental work. Fresh food plant was clover Medicago sativa along the period of study except few weeks every year because of the absence of this plant species. During these weeks, insects were fed on Sesbania eagyptiaca. All experiments were conducted with $M$. sativa only.

\section{II) Plant Extracts:}

Fagonia bruguieri var. bruguieri is a perennial wild herb distributed all deserts in Egypt but profusely spread in Sinai. It is, also, distributed in Arabia, Syria, Jordon, Iraq, Palestine, Iran, Pakistan, Afghanistan and North Africa. It 
systematically belongs to family Zygophyllaceae. The aerial parts of the plant (leaves, stems and flowers) were collected from the region of Santa Catherin (Sinai) during flowering stage, and kindly identified by Dr. Abdo marey, Faculty of Science, Al-Azhar University (Cairo). The collected samples were airdried, powdered and kept in tightly closed amber coloured glass containers for protecting from light, at low temperature.

Dried and pulverized powder of $F$. bruguieri (2 $\mathrm{kg})$ was exhaustively separately extracted with methanol (1.7 Lx3). The combined alcohol extracts were concentrated to $400 \mathrm{ml}$, diluted with 400 $\mathrm{ml}$ of water and the next successively extracted with petroleum ether $(5 \times 400 \mathrm{ml})$ was concentrated to dryness under reduced pressure giving $(80 \mathrm{~g})$, while $\mathrm{n}$-butanol $(5 \times 400$ $\mathrm{ml}$ ) extracts were concentrated to dryness under reduced pressure giving $(60 \mathrm{~g})$.

\section{III) Nymphal Treatments:}

Tow concentration levels of the methanolic extract $(7.5$ and $3.7 \%)$ were used as well as 30.0 and $15.0 \%$ of the petroleum ether extract and n-butanolic extract were used.

The newly moulted $4^{\text {th }}$ (penultimate) instar nymphs of $S$. gregaria were fed on fresh leaves of M. sativa after dipping in different concentration levels of each extract. After dipping for three minutes, the treated leaves were allowed to dry before offering to the nymphs. A day after treatment, all nymphs (treated and control) were provided with untreated food plant. Ten replicates (one nymph/replicate) were used for each concentration. Each individual nymph was isolated in a glass vial provided with a thin layer of sterilized sand as a floor.

\section{III) Enzymological Investigation:}

\section{(1) Enzyme preparation:}

For the determination of acid

phosphatase (ACP) and alkaline phosphatase (ALP) activities in the fat body, samples of this tissue were collected from $5^{\text {th }}$ instar nymphs of different ages (early, mid and late) and early adults, after treatment the early $4^{\text {th }}$ instar nymphs. The fat body samples were weighed and then homogenized in a saline solution (the fat body of one insect / $1 \mathrm{ml}$ saline solution $0.7 \%$ ) using a fine electric homogenizer, tissue grinder for $2 \mathrm{~min}$. Homogenates were centrifuged at 4000 r.p.m. for $15 \mathrm{~min}$. The supernatant was used directly or frozen until the use for the enzymatic determination. Three replicates were used and the fat bodies from two individuals were avoided to be mixed.

For the determination of the ACP and ALP activities in the haemolymph, it was collected from $5^{\text {th }}$ (last) instar nymphs of the same ages and early emerged adults, after treatment the early $4^{\text {th }}$ (penultimate) instar nymphs. Haemolymph was drawn into Eppendorff Pipetman containing few milligrams of phenoloxidase inhibitor (phenylthiourea) to prevent tanning or darkening and then diluted $5 \times$ with saline solution $0.7 \%$. For whole blood assays, the diluted haemolymph was frozen for $20 \mathrm{~s}$ to rupture the haemocytes. The haemolymph samples were then centrifuged at 2000 r.p.m. for $5 \mathrm{~min}$, and only the supernatant fractions were used for assay directly or frozen until use. Three replicates were used and the haemolymph of two individuals were never mixed.

(2) Measurement of Phosphatases:

The ACP activity was determined according to the method of (Tietz, 1986) using a kit of Bioadwic. The enzyme was measured at wave length $405 \mathrm{~nm}$ by spectrophotometer. The ALP activity was determined according to the method of (Klein et al 1960) using a kit of Quimica clinical aplicada S.A. the measured at wave length $550 \mathrm{~nm}$ by spectrophotometer.

IV) Statistical Analysis of Data:

Data obtained were analyzed by the Student's $t$-distribution, and refined by Bessel correction (Moroney, 1956) for the test significance of difference between means.

\section{RESULTS}

1) Effects of $F$. bruguieri extracts on the acid phosphatase activity in haemolymph:

The penultimate instar nymphs of $S$. gregaria were fed on clover leaves treated with each of two concentration levels of methanolic, petroleum ether or n-butanolic extracts of $F$. bruguieri. Then, the acid phosphatase (ACP) activity was investigated in the haemolymph of last instar nymphs as well as in the newly emerged adults. As seen in Fig.1 (I), the ACP activity followed a curved course whose funds occurred in the mid-aged 
nymphs $(1050.0 \pm 37.5,1200.0 \pm 37.5$ and $1425.0 \pm 37.5 \mathrm{U} / \mathrm{L}$ in early-, mid- and lateaged nymphs, respectively). Data represented in the same figure clearly show enhancing or inhibitory effects of $F$. bruguieri extracts, depending on the nymphal age or developmental stage. For more details, the ACP activity in haemolymph of both the early- and lateaged nymphs was significantly promoted while haemolymph of the mid-aged nymphs contained remarkably reduced enzyme activity. The strongest enhancing effect of $F$. bruguieri was exhibited in the early-aged nymphs after treatment with the lower concentration level of methanolic extract (Change\%: +75.0 , Table 1) but the least enhancing effect was exhibited in the late-aged nymphs after treatment with the lower concentration level of petroleum ether extract (Change\%: +4.4).

Table (1): Effects of Fagonia bruguieri extracts on the acid phosphatase activity (U/ L) in haemolymph of the desert locust Schistocerca gregaria.

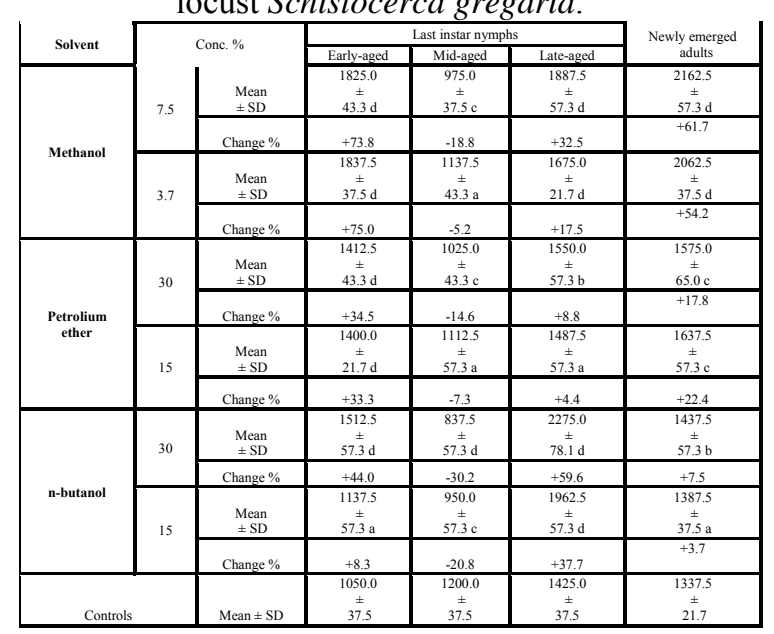

Conc.: Concentration, mean \pm SD followed with the same letter (a): is not significantly different ( $\mathrm{P}>0.05)$, (b): significantly different $(\mathrm{P}<0.05)$, (c): highly significantly different $\quad(\mathrm{P}<0.01), \quad(\mathrm{d})$ : very highly significantly different $(\mathrm{P}<0.001)$.

Concerning with the newly emerged adults, haemolymph appeared with pronouncedly induced ACP activity as a response to the nymphal treatment with $F$. bruguieri extracts, irrespective of the solvent used or concentration level applied. However, the strongest enhancing effect on the enzyme activity was exhibited by the methanolic extract $(2162.5 \pm 57.3 \mathrm{U} / \mathrm{L}$ at the higher concentration level (in comparison with $1337.5 \pm 21.7 \mathrm{U} / \mathrm{L}$ of control congeners) but the minimal enhancing one was observed after the treatment with n-butanolic extract (1387.5 $\pm 37.5 \mathrm{U} / \mathrm{L}$ at the lower concentration level, compared to $1337.5 \pm 21.7 \mathrm{U} / \mathrm{L}$ of control congeners).

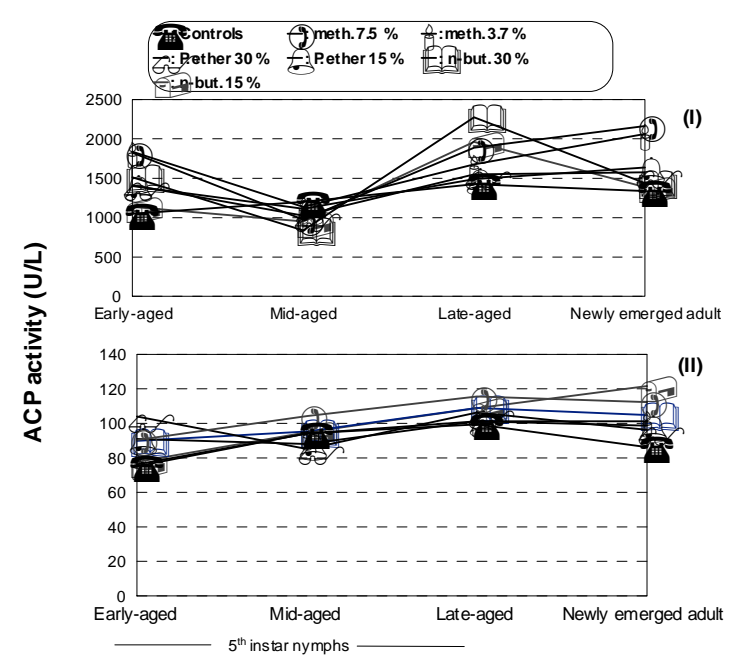

Fig. (1): Effects of Fagonia bruguieri extracts (methanol, petroleum ether and n-butanol) on the acid phosphatase activity in haemolymph (I) and fat body (II) of Schistocerca gregaria .

\section{2) Effects of $F$. bruguieri extracts on the ACP activity in fat body:}

According to the data illustrated in Fig.1 (II), a major inducing effect of $F$. bruguieri extracts on ACP activity in the fat body was observed in the last instar nymphs, with few exceptions. Only petroleum ether extracts (Change \%: - 9.6 and -6.5 at higher and lower concentration levels, respectively, Table 2) and methanolic extracts (Change \%:- 0.1 at lower concentration level only) prohibited the ACP activity.

In addition, the strongest enhancing effect of $F$. bruguieri extracts on ACP activity was exhibited in fat body of the late-aged nymphs $(115.6 \pm 3.0$ vs. $99.4 \pm 1.1$ $\mathrm{U} / \mathrm{L}$ of control congeners) after treatment with higher concentration level of methanolic extract but the least enhancing one was exhibited in fat body of the midaged nymphs $(94.8 \pm 2.5$ compared to $94.2 \pm 1.2 \mathrm{U} / \mathrm{L}$ of control congeners) after treatment with the lower concentration level of n-butanolic extract.

With regard to the newly emerged adults, data of the same table obviously show the strongest inducing effect of $F$. 
bruguieri extracted by n-butanol (Change $\%$ : +40.9 at lower concentration level) while the least inducing one (Change \%: +11.5 ) was exhibited after treatment with the higher concentration level of petroleum ether extract.

Table (2): Effects of Fagonia bruguieri extracts on the acid phosphatase activity (U/L) in fat bodies of the desert locust Schistocerca gregaria.

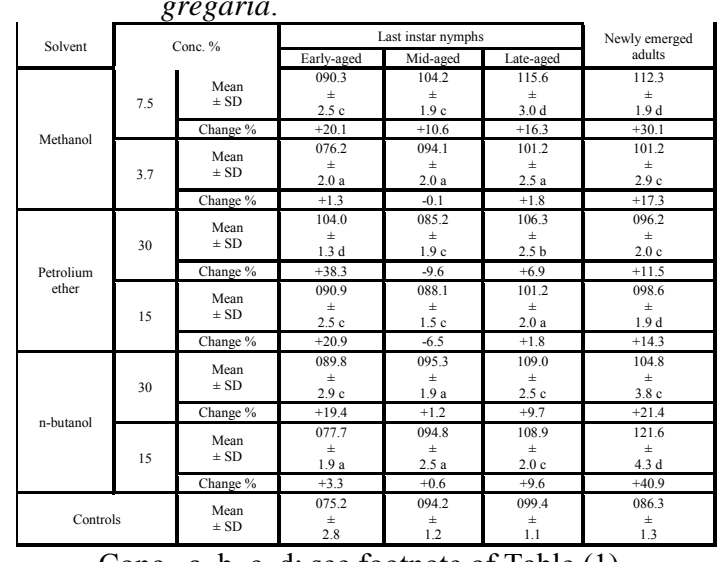

Conc., a, b, c, d: see footnote of Table (1).

3) Effects of $F$. bruguieri extracts on the alkaline phosphatase activity in haemolymph:

Another experimental work was carried out to explore the possible effects of $F$. bruguieri extracts on the alkaline phosphatase (ALP) activity in two tissues: haemolymph and fat body of last instar nymphs and newly emerged adults of $S$. gregaria. Fig.2 (I) shows the obtained data of ALP fluctuations in the haemolymph of nymphs and adults.

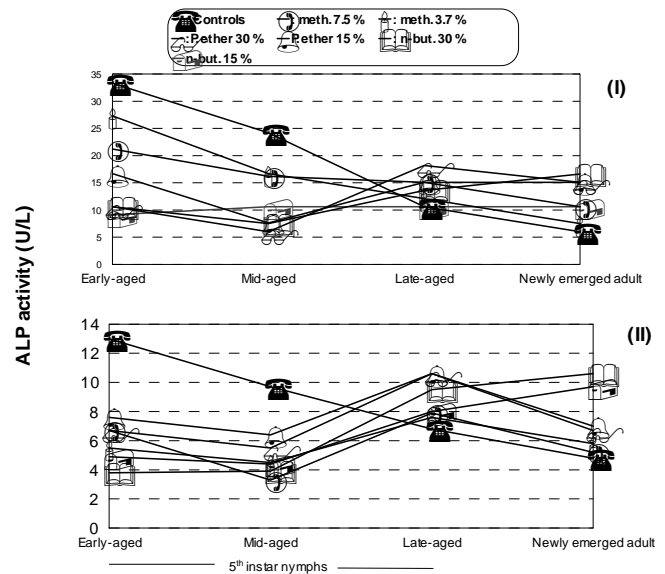

Fig. (2): Effects of Fagonia bruguieri extracts (methanol, petrolium ether and n-butanol) on the alkaline phosphatase activity in the haemolymph (I) and fat body (II) of Schistocerca gregaria after treatment of the early 4 th instar nymphs.
The F. bruguieri, extracted with all organic solvents, exerted contradictory effects on nymphs depending on the age because the early- and mid-aged nymphs had haemolymph with highly significantly decreased ALP activity but induced enzyme activity in haemolymph of the late-aged ones. Moreover, the strongest inhibitory effect of $F$. bruguieri extracts was detected in the mid-aged nymphs after treatment with petroleum ether extract (6.0 $\pm 2.7 \mathrm{U} / \mathrm{L}$ at higher concentration level vs. $24.2 \pm 2.7 \mathrm{U} / \mathrm{L}$ of control congeners).

Data arranged in Table (3) clearly show a considerable enhancing effect of $F$. bruguieri extracts on the ALP activity in haemolymph of newly emerged adults. The most potent stimulating effect was achieved by the higher concentration level of n-butanol extract (Change \%: +176.7) while the least stimulating one was exhibited after treatment with the lower concentration level of methanolic extract (Change\%: +25.0).

Table 3: Effects of Fagonia bruguieri extracts on the alkaline phosphatase activity $(\mathrm{U} / \mathrm{L})$ in haemolymph of the desert locust Schistocerca gregaria.

\begin{tabular}{|c|c|c|c|c|c|c|}
\hline \multirow{2}{*}{ Solvent } & \multirow{2}{*}{\multicolumn{2}{|c|}{ Conc. $\%$}} & \multicolumn{3}{|c|}{ Last nymphal instar } & \multirow{2}{*}{$\begin{array}{c}\text { Newly } \\
\text { emerged } \\
\text { adults }\end{array}$} \\
\hline & & & $\begin{array}{l}\text { Early- } \\
\text { aged }\end{array}$ & $\begin{array}{l}\text { Mid- } \\
\text { agedd }\end{array}$ & $\begin{array}{ll}\text { Late- } \\
\text { aaed }\end{array}$ & \\
\hline \multirow{4}{*}{ Methanol } & \multirow[t]{2}{*}{7.5} & $\begin{array}{c}\text { Mean } \pm \\
\text { SD }\end{array}$ & $\begin{array}{c}21.2 \\
\pm \\
6.1 \mathrm{a} \\
\end{array}$ & $\begin{array}{c}16.2 \\
\pm \\
2.5 \mathrm{~b} \\
\end{array}$ & $\begin{array}{r}15.1 \\
\pm \\
2.7 \mathrm{a} \\
\end{array}$ & $\begin{array}{c}10.6 \\
\pm \\
2.6 \mathrm{a} \\
\end{array}$ \\
\hline & & Change $\%$ & -36.3 & -33.1 & +42.5 & +76.7 \\
\hline & \multirow[t]{2}{*}{3.7} & $\begin{array}{l}\text { Mean } \\
\pm \text { SD }\end{array}$ & $\begin{array}{c}27.3 \\
\pm \\
4.5 \mathrm{a}\end{array}$ & $\begin{array}{c}16.7 \\
\pm \\
2.7 \mathrm{~b}\end{array}$ & $\begin{array}{c}12.1 \\
\pm \\
5.3 \mathrm{a}\end{array}$ & $\begin{array}{c}7.5 \\
\pm \\
5.3 \mathrm{a}\end{array}$ \\
\hline & & Change $\%$ & -18 & -31 & +14.2 & +25.0 \\
\hline \multirow{4}{*}{$\begin{array}{c}\text { Petrolium } \\
\text { ether }\end{array}$} & \multirow[t]{2}{*}{30} & $\begin{array}{l}\text { Mean } \\
+\mathrm{SD}\end{array}$ & $\begin{array}{c}10.6 \\
\pm \\
2.6 \mathrm{c}\end{array}$ & $\begin{array}{c}6.0 \\
\pm \\
2.7 \mathrm{c}\end{array}$ & $\begin{array}{c}18.2 \\
\pm \\
4.5 \mathrm{a}\end{array}$ & $\begin{array}{c}15.1 \\
\pm \\
2.7 \mathrm{~b}\end{array}$ \\
\hline & & Change $\%$ & -68.2 & .75 .2 & +71.7 & +151.7 \\
\hline & \multirow[t]{2}{*}{15} & $\begin{array}{l}\text { Mean } \\
\pm \text { SD }\end{array}$ & $\begin{array}{c}16.7 \\
\pm \\
\pm .7 \mathrm{~b}\end{array}$ & $\begin{array}{c}7.6 \\
\pm \\
.7 \mathrm{c}\end{array}$ & $\begin{array}{c}15.1 \\
\pm \\
2.7 \mathrm{a}\end{array}$ & $\begin{array}{c}15.1 \\
\pm \\
2.7 \mathrm{~b}\end{array}$ \\
\hline & & Change $\%$ & -49.8 & -68.6 & +42.5 & +151.7 \\
\hline \multirow{4}{*}{ n-butanol } & \multirow[t]{2}{*}{30} & $\begin{array}{l}\text { Mean } \\
\pm \mathrm{SD}\end{array}$ & \begin{tabular}{|c|}
10.6 \\
\pm \\
$2.6 \mathrm{c}$
\end{tabular} & $\begin{array}{c}7.5 \\
\pm \\
5.3 \mathrm{c}\end{array}$ & $\begin{array}{c}13.6 \\
\pm \\
4.5 \mathrm{a}\end{array}$ & $\begin{array}{c}16.6 \\
\pm \\
5.3 \mathrm{~b}\end{array}$ \\
\hline & & Change $\%$ & -68.2 & -69 & -28.3 & +176.7 \\
\hline & \multirow{2}{*}{15} & $\begin{array}{l}\text { Mean } \\
\pm \text { SD }\end{array}$ & $\begin{array}{c}9.1 \\
\pm \\
4.5 \mathrm{c}\end{array}$ & $\begin{array}{c}10.6 \\
\pm \\
2.6 \mathrm{c}\end{array}$ & $\begin{array}{c}10.6 \\
\pm \\
2.6 \mathrm{a}\end{array}$ & $\begin{array}{c}10.6 \\
\pm \\
2.6 \mathrm{a}\end{array}$ \\
\hline & & Change $\%$ & -72.7 & -56.2 & 0.0 & +76.7 \\
\hline \multicolumn{2}{|c|}{ Controls } & $\begin{array}{l}\text { Mean } \\
\pm \mathrm{SD}\end{array}$ & $\begin{array}{c}33.3 \\
\pm \\
6\end{array}$ & $\begin{array}{c}24.2 \\
\pm \\
\pm\end{array}$ & $\begin{array}{c}10.6 \\
\pm \\
26\end{array}$ & $\begin{array}{c}6.0 \\
\pm \\
2.7\end{array}$ \\
\hline
\end{tabular}

4) Effects of $F$. bruguieri extracts on the ALP activity in fat body:

Data of ALP activity in the fat body of nymphs and adults as influenced by $F$. bruguieri, are diagramed in Fig.2 (II). A similar trend to the effect on ALP activity in the haemolymph, F. bruguieri extracts prohibited such enzyme activity, also, in the fat body of early- and mid-aged nymphs but stimulated it in the fat body of late-aged ones, with no exception. 
Furthermore, the strongest reducing effect of $F$. bruguieri was estimated in $3.8+1.2$ $\mathrm{U} / \mathrm{L}$ within the early-aged nymphs (compared to $13.0+1.6 \mathrm{U} / \mathrm{L}$ of control congeners) after treatment with the higher concentration level of n-butanolic extract while the least reducing effect was estimated in $6.4+0.9 \mathrm{U} / \mathrm{L}$ within the midaged nymphs (compared to $9.7+1.0 \mathrm{U} / \mathrm{L}$ of controls) after treatment with the lower concentration level of petroleum ether extract.

An extended enhancing effect of $F$. bruguieri on the ALP activity in fat body was appreciated in the newly emerged adults. The strongest enhancing effect was represented in Change \% as +120.8 (after treatment with the higher concentration level of n-butanolic extract, Table 4) but the slightest enhancing one was represented in Change \% as +8.3 (after treatment with the higher concentration level of methanolic extract).

Table (4): Effects of Fagonia bruguieri extracts on the alkaline phosphatase activity $(\mathrm{U} / \mathrm{L})$ in fat bodies of the desert locust Schistocerca gregaria.

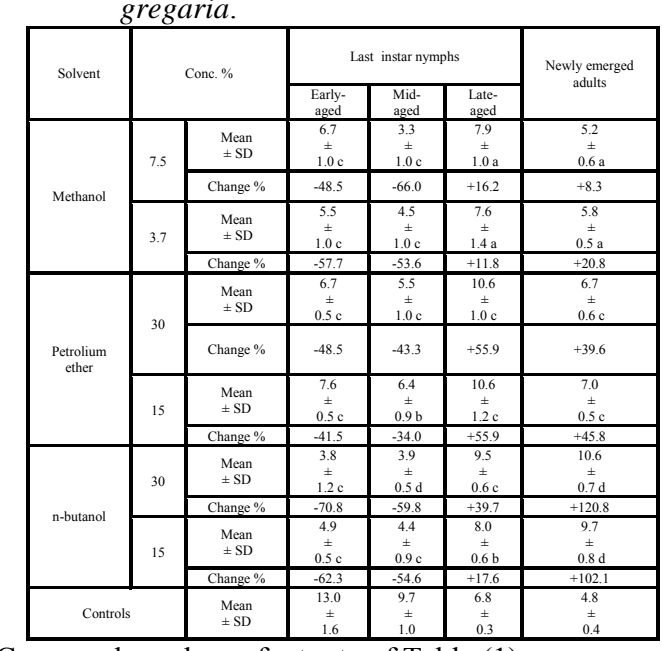

Conc., a, b, c, d: see footnote of Table (1).

\section{DISCUSSION}

1) Affected Acid Phosphatase Activity by $F$. bruguieri:

Various effects on the ACP activity were reported for different insect species because the neem extract RB-a was less effective on the enzyme activity of Culex fatigans than other neem extracts RBU-9 and Margosan-0 (Naqvi et al., 1995) as well as RB-b was more effective than RB-a but less than effective the insecticide parathion on ACP activity of
Anopheles stephensi (Rajput, 2003). Also, Ghoneim et al. (2008) recorded some various inducing and reducing effects of Margosan- 0 and Jojoba oil on the enzyme activity during the pupal stage of Musca domestica depending on the pupal age and concentration levels.

In the present study on $S$. gregaria, the haemolymph of both the early- and late-aged nymphs contained remarkably prohibited ACP activity while a strong inducing effect of $F$. bruguieri was exhibited only in the early-aged nymphs, after treatment with the lower concentration level of methanolic extract (Change \%: +75.0). Haemolymph of the newly emerged adults appeared with pronouncedly induced ACP activity, irrespective of the solvent or its concentration level. A major inducing effect of F. bruguieri extracts on ACP activity in the fat body in last instar nymphs was significantly or insignificantly observed, with few exceptions. The strongest inducing effect was exhibited on the enzyme activity in fat body of the newly emerged adults by nbutanol extract (Change \%: +40.9 at lower concentration level).

However, the major inducing effect of $F$. bruguieri extracts on the ACP activity in haemolymph of $S$. gregaria, in the present study, agrees with several reported results of induced ACP activity in larvae of $M$. domestica (Barker and Alexander, 1958), Helicoverpa armigra (Babu et al., 1996), Stomoxys calcitrans (Spates and Wright, 1975), Spodoptera littoralis (Hassan, 2002) and Rhynchophorus ferrugineus (Bream, 2003).

Moreover, the inhibitory effects of some of the present plant extracts on ACP activity during the later nymphal days are in agreement with those inhibitory effects of other plant extracts such as azadirachtin (Azt.) against $M$. domestica (Saeed et al., 1987) and S. littoralis (Ayyangar and Rao, 1990); NFD (a fraction of winter neem leaves) against Sitophilus oryzae (Naqvi et al.,1991); extracts from Ammi majus, Apinum graveolens, Melia azedarach and Vinea rosea against Agrotis ipsilon (Abo El-Ghar et al., 1995); certain plant extracts against S. littoralis (Bakr et al., 2002); 
some neem limonoids against Euprepocnemis plorans (A1-Dali, 2007); Margosan-0 and Jojoba oil against $M$. domestica (Ghoneim et al., 2008).

The inhibited ACP activity, in the present study, may be due to strong inhibition of ecdysone, which is followed by subsequent decrease in number of lysosomes and in turn decreased the lysosomal ACP activity (Hassan, 2002). Moreover, the decreased levels of ACP activity suggests a reduced phosphorous libration for energy metabolism, decreased rate of metabolism as well as decreased rate of transport of enzyme regulation (Senthil Nathan et al., 2005). In addition, the increasing ACP activities in the adults of $S$. gregaria by the action of some extracts from $F$. bruguieri, in the present study, may be attributed to the consumption and utilization of large quantities of food (Miao, 2002; Senthil Nathan and Saehoon, 2005). Moreover, the ACP activity, directly or indirectly, interferes with the digestion, absorption and positive transport of nutrient in the mid-gut (Smirle et al., 1996; Senthil Nathan et al., 2004). It may be important to recall the conclusion of Bassal and Ismail (1985) that suitable levels of ecdysone are required to increase the number of lysosomes, and hence ACP activity increment.

2) Affected Alkaline Phosphatase Activity by F. bruguieri:

$F$. bruguieri, extracted by all organic solvents, exerted in the present study some contradictory effects on the ALP activity in the haemolymph of $S$. gregaria nymphs, in the present study, depending on the age because the earlyand mid-aged nymphs appeared with significantly decreased enzyme activity but induced activity in the late-aged ones. A considerable enhancing effect of $F$. bruguieri on the ALP activity in haemolymph of the newly emerged adults was determined. In respect to the ALP activity in fat body, F. bruguieri extracts prohibited it in the early- and mid-aged nymphs but stimulated it in the late-aged ones. An enhancing effect on the enzyme activity in fat body of the newly emerged adults was appreciated.
Induced or reduced ALP activity was determined in various insects by the action of some plant extracts, juvenoids or insect growth regulators, as reported in the literature. Considerably decreasing ALP activity after treatment of Chrysomia albiceps larvae with some juvenile hormone analogues was measured (Ismail, 1980). Reducing effect of Azt. on the activity of this enzyme in Spodoptera litura $6^{\text {th }}$ instar larvae was reported (Ayyangar and Rao, 1990). Also, reduced activity of ALP was recorded after treatment of Culex pipiens $3^{\text {rd }}$ instar larvae with some other plant extracts (El-Bokl et al., 1998). Feeding of S. litura on Ricinus communis leaves treated with Azt. decreased the ALP activity in the mid gut (Senthil Nathan et al., 2005). Also, consumption of Melia azedarach seed extract-containing rice leaf diet resulted in a $71 \%$ reduction of ALP activity in Cnaphalocrocis medinalis (Senthil Nathan, 2006). Remarkable reducing effects of some limonoids (neem extracts) on ALP activity in the mid gut of the later nymphal instars of $E$. plorans were estimated (Al-Dali, 2007). After treatment of the $5^{\text {th }}$ instar larvae of Bombyx mori with the juvenoid pyriproxyfen caused a significant decrease of ALP level during $24 \mathrm{~h}$ post-treatment and it could not recover its normal level even in $120 \mathrm{~h}$ (Etebari et al., 2007).

However, the reduced ALP activity at different time points in the last instar nymphs and adults of $S$. gregaria by F. bruguieri extracts, in the present study, may be attributed to some developmental disturbance as previously suggested by Wu-Tsiu Yan and Wu-Ty (1990) for the mosquito larvae of $C$. pipiens after treatment with the insecticide diflubenzuron (Dimilin). In addition, $F$. bruguieri may affect the gut physiological events (i.e. transport) causing a prohibition of ALP activity, as well as may influence both the juvenile hormone and ecdysone controlling, directly or indirectly, as suggested by Sridhara and Bhat (1963) in B. mori. On the other hand, the increasing ALP activity level in fat body of the last instar nymphs of $S$. gregaria, especially at the late age and the newly emerged adults, in the present study, might indicate the 
involvement of ALP in detoxification process against the toxicants contained in the present plant extracts (Shekari et al., 2008).

\section{REFERENCES}

Abo El-Ghar, G. E. S.; Khalil, M. E. and Eid, T. M. (1995): Some biochemical effect of plant extracts in the black cutworm Agrotis ipsilon (Hufinagal) (Lepidoptera: Noctuidae). J. Appl. Entomol., 120 (8): 477-482.

Al-Dali, A. G. (2007): Influenced activities of the intestine acid and alkaline phosphatases by some neem limonoids in the grasshopper Euprepocnemis plorans (Orthoptera: Acrididae). J. Egypt. Acad. Soc. Environ. Develop., 8(3): 57 - 65.

Ayyangar, G. S. G. and Rao, P. J. (1990): Azadirachtin effects on consumption and utilization of food and midgut enzymes of Spodoptera littura (Fabr.). Indian J. Entomol., 51: 373 - 376.

Babu, R. ; Murugan, K. and Vanithakumari, G. (1996): Interference of azadirachtin on the food utilization efficiency and gut enzymatic profiles of Helicoverba armigera Hubner (Lepidoptera: Noctuidae). Indian J. Environ. Toxicol., 6(2): $81-84$.

Bakr, F. R.; El-bermawy, S.; Emara, S.; Abulyazid, I. and Abdlwwahab, H. (2002): Biochemical studies on Spodoptera littoralis developmental stages after larval treatment with different botanicals extracts. Proc. $2^{\text {nd }}$ Int. Conf. Plant Prot. Res. Inst., Cairo, Egypt, 1: 888 - 893.

Barker, H. S. and Alexander, B. H. (1958): Acid and alkaline phosphatases in house flies of different stages. Ann. Entomol. Soc. Amer., 51: 255 - 257.

Bassal, T. T. M. and Ismail, E. I. (1985): Acid and alkaline phosphatases of normal and juvenilized Spodoptera littoralis (Noctuidae: Lepidoptera) during metamorphosis. Proc. Zool., Soc. A. R. Egypt, 9: 259 - 266.

Benner,J.P. (1993): Pesticidal compounds from higher plants. Pesticide Sci., 39(2):95-102.

Bream, A. S. (2003): Effect of Azadirachtin on phosphatases and transaminases activities in pupae of the red palm weevil, Rhyncophorus ferrugineus (Coleoptera: Curculionidae). Proc. Int. Conf. on Date Palm, 16 -19 Sep.

Cheung, W. W. K. and Low, K. W. (1975): Ultrastructural and functional differentiation of the midgut of the sugar cane beetle Protaetia acuminate (F.) (Coleoptera: Cetoniidae). Int. J. Insect Morphol. Entomol., 4: 349 - 361.
Dadd, R. H. (1970): Arthropoda nutrition. In: "Chemical Zoology" (eds.: Florkin M, Scheer Bt,). vol. 5., Academic Press New York, pp: $35-95$.

Dhadialla, T. S.; Carlson, G. R. and Le, D. P. (1998): New insecticides with ecdysteroidal and juvenile hormone activity. Annu. Rev. Entomol., 43: 545569.

El-Bokl, M. M.; Hamed, M. S. and Moawad, H. M. (1998): Effects of sublethal dosage of plant extracts and cypermethrin on certain biochemical aspects of the first filial generation of Culex pipiens larvae. J. Egypt. Ger. Soc. Zool., 26: 45 - 55.

Etebari, K.; Bizhannia, A. R.; Sorati, R. and Matindoost, L. (2007): Biochemical changes in haemolymph of silkworm larvae due to pyriproxyfen residue. Pestic. Biochem. Physiolo., 88: 14-19.

Ferreira, C. and Terra, W. R. (1980): Intracellular distribution of hydrolases in midgut caeca cells from an insect with emphasis on plasma membrane-bound enzymes. Comp. Biochem. Physiol., 66(B): $467-473$.

Ghoneim, K. S. ; Abdel-Ghaffar, A. A. and Tanani, M. A. (2008): Changes of acid phosphatases activity by the plant extracts, Margosan-O and Jojoba, during the pupal stage of Musca domestica (Diptera: Muscidae). J. Egypt. Acad. Sci. Environ. Develop., 9(1): 47-55.

Hassan, H. A. (2002): Biological and biochemical studies on the effects of some botanical extracts on cotton leafwom Spodoptera littoralis (Boisd.) (Lepidoptera: Noctuidae). Unpublished M. Sc. Thesis, Fac. Sci., Ain Shams Univ., Egypt.

Hassanein, M.S. (1965): Laboratory and outdoor cultures and breeding of locusts and grasshoppers. FAO Publ., 5/31901, 10 pp.

Hollander, V. P. (1971): Acid phosphatases. In: "the Enzyme". (ed. Boyer P.), $3^{\text {rd }}$ Academic Press, New York.

Hunter-Jones, P. (1961): Rearing and breeding locusts in the laboratory. Bull. Anti-locust Res. Center London, 12 Pp.

Ismail, I. E. (1980): Physiological studies on the effect of juvenile hormone analogues on the cotton leaf worm, Spodoptera littoralis (Boisd.). Unpublished Ph. D. Thesis, Cairo Univ., Egypt.

Jacopson, M. (1975): Insecticides from plants. A review of literature. USDA Agric. Hand book No. 461: 1945- 71.

Josephrajkumar, A.; Subrahmanyam, B. and Srinivasan (1999): Plumbagin and 
azadirachtin deplete haemolymph ecdysteroid levels and alter the activity profiles of two lysosomal enzymes in the fat body of Helicoverba armigera (Lepidoptera: Noctuidae). Eur. J. Entomol., 96: $347-353$.

Khoja, S. M. (1991): Alkaline phosphatase from the excretory system of the grasshoppers, Poekilocerus bufonius. Insect Biochem., 21: 239 - 242.

Klein, B. ; Read, P. A. and Babson, L. A. (1960): Clinical Chemistry. 6: 269-275.

Miao, Y. (2002): Studies on the activity of the alkaline phosphatase in the midgut of infected silkworm, Bombyx mori L. J. Appl. Entomol., 126: 38-142.

Moroney, M. J. (1956): Facts from figures ( $3^{\text {rd }}$ ed.). Penguin Books Ltd., Harmondsworth. Middle Sex.

Naqvi, S. N. H.; Jahan, M.; Tabassum, R.; Omar, S. J. and Ahamed, I. (1995): Toxicity and teratogency caused by coopex 25EC and a neem extract (N-7) against $3^{\text {rd }}$ instar larvae Musca domestica L. Pakistan. J. Zool., 27(1): 27 - 31.

Naqvi, S. N. H. ;Akhtar, K. and Azmi, M. A. (1991): Toxicity of NfD against Sitophilus oryzae L. exposed to impregnated filter paper and its effects on phosphatases and protein metabolites. Acta Biologica. Crac. Zoologia Ser. XXXIII.,49 - 58.

Rajput, M. T. (2003): Potential of different neem products for the control of Anopheles stephensi and their effect on morphology and enzyme pattern. Unpublished Ph.D. Thesis, Univ. Karachi, Pakistan.

Rees, H. H. (1995): Ecdysteroid biosynthesis and inactivation in relation to function. Eur. J. Entomol., 92: 9-39.

Rembold H.; Sharma, G.K.; Czoppelt, C. and Schmutterer H. (1980) Evidence of growth disruption in insects without feeding inhibition by neem seed fractions, $\mathrm{Z}$. Pflanzenkd. Pflanzenschutz. 87, 290-297.

Rhadha, P. and Priti, S. N. (1969): Phosphatase activity in Philosamia ricini during development. Indian J. Biochem., 6: 154 156.

Saeed, S. A. ; Naqvi, S. N. H. and Akhtar, K. (1987): Toxicity of NfC (neem extract) against Musca domestica L. and their effect on esterase activity. Zoologica Pakistan, 1(1): 25 - 39.

Schin, K. S. and Clever, U. (1965): Lysosomal and free acid phosphatase in salivary glands of Chironomus tentans. Sci. Wash., 150: $1053-1055$.

Schmutterer, H. (1985): Insect pests can be controlled by application of neem kernel extracts under field conditions. Z. Angew. Entomol . 100:468-475.

Schmutterer, H. and Ascher, K. R. S. (1984): Natural pesticides from the tree and other tropical plants. Proc. $2^{\text {nd }}$ Int. Neem Conf. Rauischholzhausen FRG. 25 - 28 May 1983.

Senthil Nathan, S.; Chung, P. G. and Murugan, K. (2004): Effect of botanicals and bacterial toxin on the gut enzyme of Cnaphalocrocis medinalis, Phytoparasitica 32: 433-443.

Senthil Nathan, S. and Saehoon, K. (2005): Effects of Melia azedarach L. extract on the teak defoliator Hyblaea puera Cramer (Lepidoptera: Hyblaeidae). Crop Prot., in press.

Senthil Nathan, S.; Kalaivani, K. and Chung, P. G. (2005): The effects of azadirachtin and nucleopolyhedrovirus on midgut enzymatic profile of Spodoptera litura Fab. (Lepidoptera: Noctuidae), Pestic. Biochem. Physiol. 83 46-57.

Senthil Nathan S.; Kalaivani, K. and Murugan, K. (2006): Behavioural responses and changes in biology of rice leaffolder following treatment with a combination of bacterial toxins and botanical insecticides. Chemosphere, 64: 1650 - 1658.

Shekari, M. ; Sendi, J. J. ; Etebari, K. ; Zibaee, A. and Shadparvar, A. (2008): Effects of Artemisia annua L. (Asteracea) on nutritional physiology and enzyme activities of elm leaf beetle, Xanthogaleruca luteola Mull. (Coleoptera: Chrysomellidae). Pestic. Biochem. Physiol., 91: 66 - 74.

Smirle, M. J.; Lowery, D. T. and Zurowski, C. L., (1996): Influence of Neem oil on detoxication enzyme activity in the oblique banded leafroller, Choristoneura rosaceana. Pestic. Biochem. Physiol., 56: $220-230$.

Smith, S. L. (1985): Regulation of ecdysteroid titer: synthesis. In "Comprehensive Insect Physiology, Biochemistry and Pharmacology" (eds.: Kerkut G. A. \& Gilbert L. I.), Vol. 7. Pergamon Press, London, Pp: 295 - 341.

Spates, G. E. and Wright, J. E. (1975). Effects of juvenile hormone analogue on phosphatase activity in pupae of the stable fly Stomoxys calcitrans. J. Insect Physiol., 21: $1789-1792$.

Sridhara, S. and Bhat, J. V. (1963): Alkaline and acid phosphatases of the silkworm, Bombyx mori L. J. Insect Physiol., 9: 693 -701 .

Srivastava, J. P. and Saxena, S. C. (1967). On the alkaline and acid phosphatases in the 
alimentary tract of Periplaneta americana L. Appl. Entomol. Zool., 2: 85 - 92.

Tietz, N. W. (1986). Text Book of Clinical Chemistry. W. B. Saunders Co., London, Philadelphia.

Wigglesworth, V. B. (1972). The principle on Insect physiology. $7^{\text {th }}$ ed. Chapman \& Hall, London.
Wolfersberger, M. G. (1984). Enzymology of plasma membranes of insect intestinal cells. Amer. Zool., 24: 187 - 197.

Wu-Tsiu Yan and Wu-Ty (1990). Effects of diflubenzuron on phosphatases activities in the larvae of Culex pipiens fatigans. Acta Entomolo. Sinica, 33 (1): 71-76.

\section{ARABIC SUMMARY}

$$
\begin{aligned}
& \text { فعالية تأثير النبات البري فاجونيا بروجيري (الفصيلة الطرطراوية) على أنثطة الإنزيمات الفوسفاتية }
\end{aligned}
$$

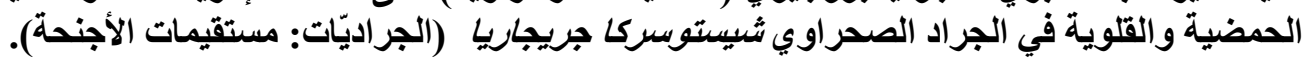

$$
\begin{aligned}
& \text { أحمد لطفي بسيوني- خالد شوقي حمادة- محمد علي طناني } \\
& \text { كلية العلوم جامعة الأز هر - مدينة نصر ـ القاهرة مئرة }
\end{aligned}
$$

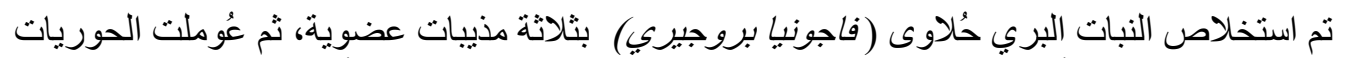

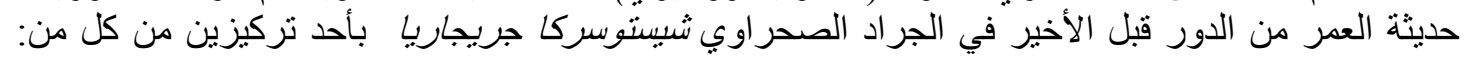

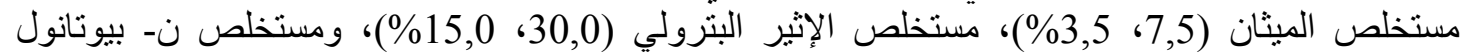

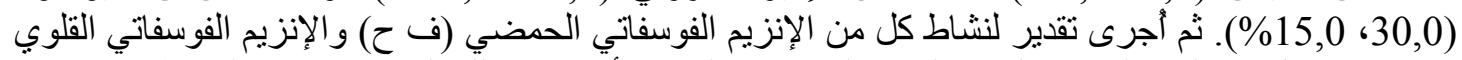

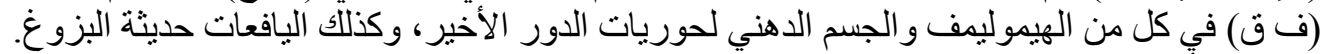

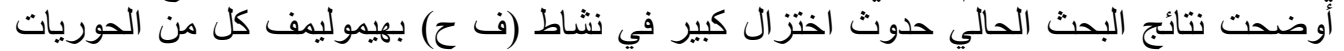

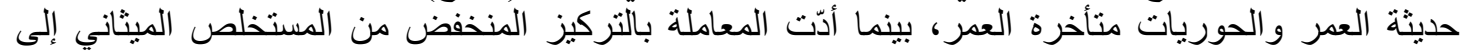

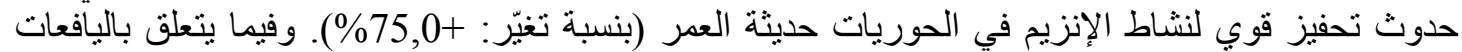

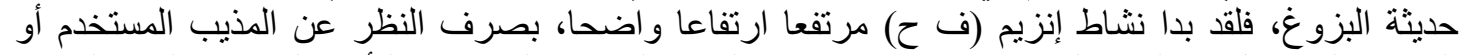

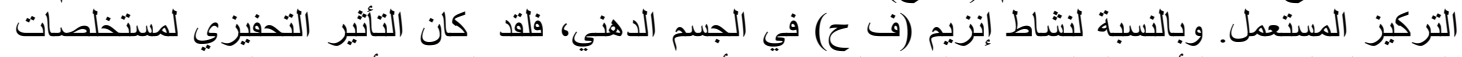

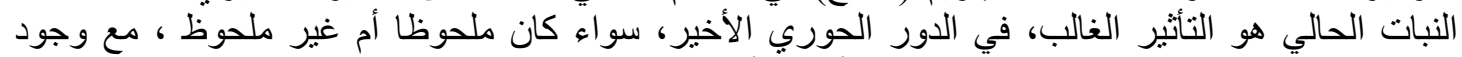

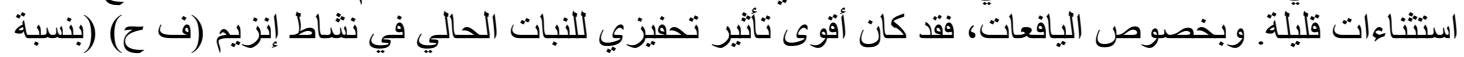

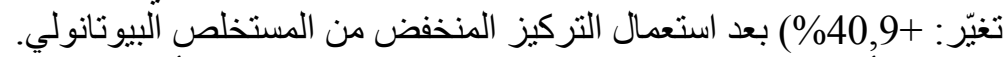

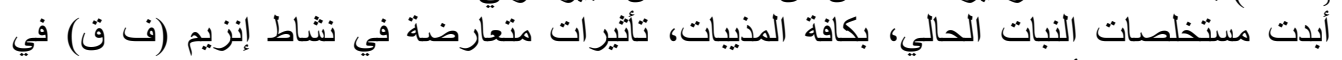

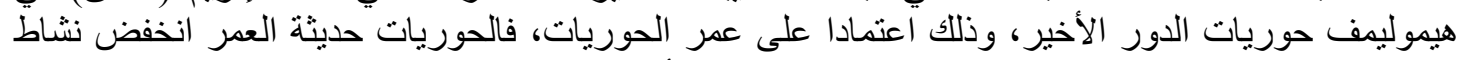

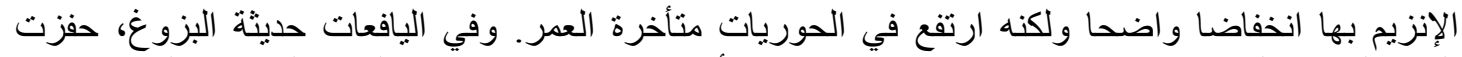

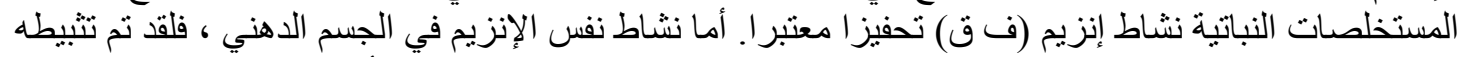

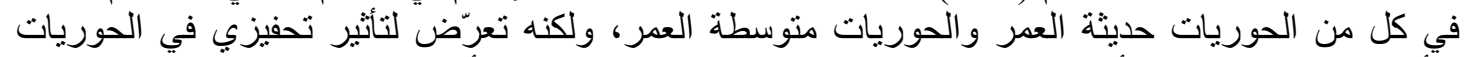
متأخرة العمر . كما كان التأثير في نشاط هذا الإنزيم بالجسم الدهني لليافعات تأثئير ا تحفيزيا. 